\title{
Farmyard drug use a US battlefield and a Canadian wasteland
}

$\mathrm{T}$ he contrast is alarming, experts say. In the United States, judicial decisions and regulatory announcements are becoming daily fodder for news mills as the evidence mounts against subtherapeutic farmyard use of antibiotics.

The consequences of growing antimicrobial resistance on the treatment of human diseases has become so worrisome that the World Health Organization (WHO) urged a crackdown on farm use as part of a broader action plan to contain resistance (http://whqlib doc.who.int/publications/2012/9789241 503181_eng.pdf), while Dr. Margaret Chan, WHO's director-general, warned that the world stands on the precipice of "the end of modern medicine" (www.cmaj.ca/lookup/doi/10.1503/cmaj .109-4164).

The Canadian response?

Utter silence.

It's doubly ironic, the experts add, given that Canadian research and surveillance played a contributory factor in several US Food and Drug Administration (FDA) measures, including a recent ban on off-label use of cephalosporins in most food-producing animals (www .cmaj.ca/lookup/doi/10.1503/cmaj.109 $-4094)$.

"The juxtaposition is bizarre," notes Jim Hutchinson, medical director for antibiotic stewardship at the Vancouver Island Health Authority in Victoria,
British Columbia. "Canadian government-funded research is influencing sensible policy changes in many parts of the world but is completely ignored in Canada."

A judicial ruling and the Canadian data helped propel FDA to issue nonbinding guidance earlier this year that antibiotics important to human health be used in livestock only for medical purposes and under veterinary supervision (www.cmaj.ca/lookup/doi/10.1503 /cmaj.109-4094).

US District Court Judge Theodore H. Katz of the Southern District of New York had kickstarted a 35-year-old FDA plan to outlaw the subtherapeutic use of penicillin and tetracycline antibi-

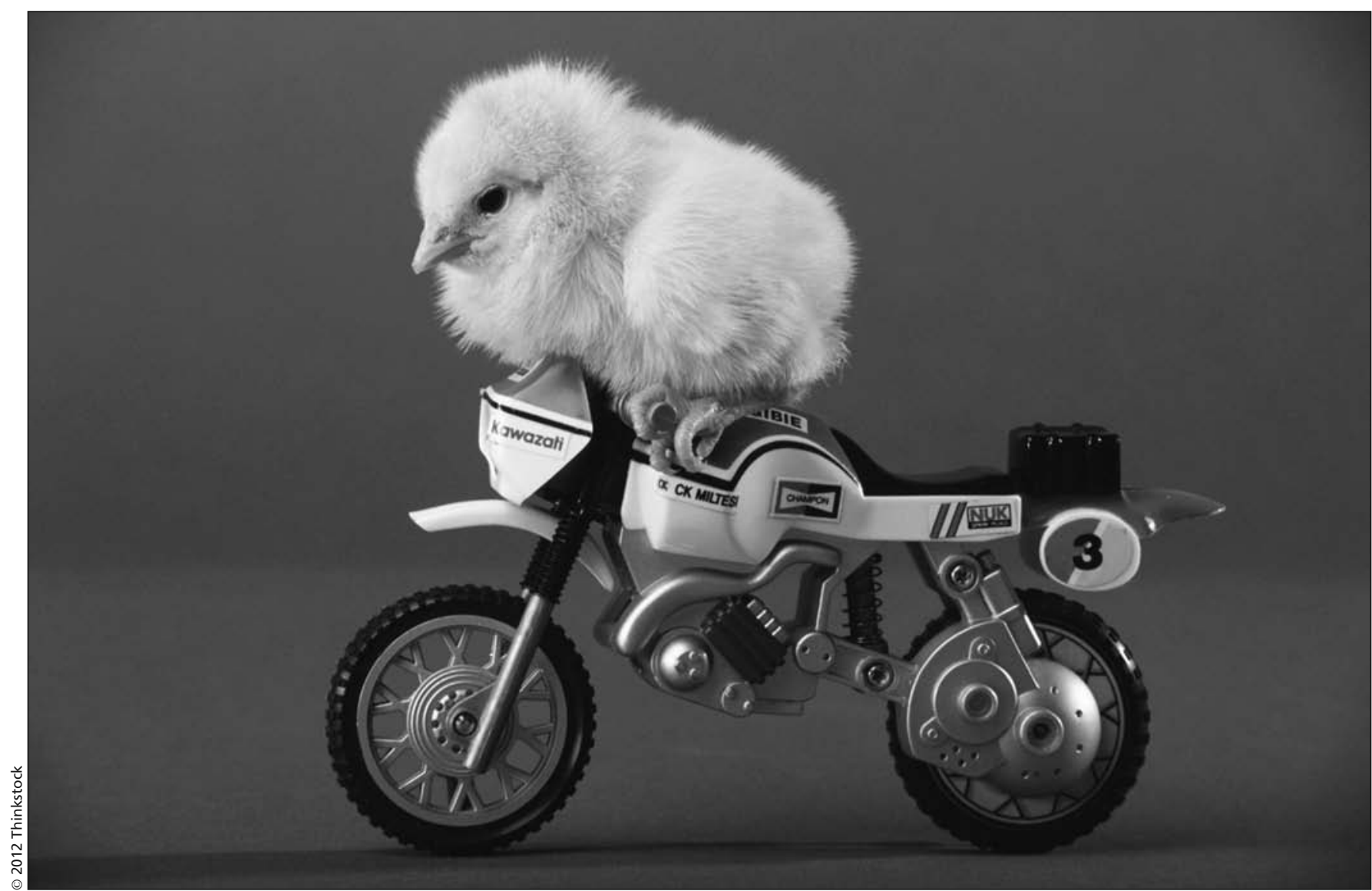

Widespread use of antibiotics to accelerate growth in chickens, swine, cattle and turkeys has led to increased rates of antimicrobial resistance among pathogens that infect humans. 
otics in animal feed by ruling that the agency has a statutory obligation to commence withdrawal proceedings when safety is an issue (http://nysd .uscourts.gov/cases/show.php?db=special \&id=162 and www.cmaj.ca/lookup/doi /10.1503/cmaj.109-4194).

Katz again waded into the battle when he ruled in June that FDA's voluntary, nonbinding guidance is not an adequate response to its statutory obligation "to ensure the safety and effectiveness of all drugs sold in interstate commerce."

In denying the citizen petitions of the Natural Resources Defense Council, the Center for Science in the Public Interest, Food Animal Concerns Trust, Public Citizen and the Union of Concerned Scientists to conduct a full evaluation of the safety of farm use of antibiotics on the grounds that doing so would be "too time consuming and resource intensive," FDA's actions were "arbitrary and capricious and otherwise not in accordance with the law," Katz ruled (www.louise.house.gov/images /stories/Order_on_Petitions_Claim.pdf).

"In an eleventh hour response, the Agency pointed to a guidance program that encourages industry to use these drugs 'judiciously,' with no hard evidence that the drug sponsors have agreed to or will agreed to the proposed measures," Katz added. "By refusing to make findings as to the drugs' safety or provide a statutorily based reason for refusing to make such findings - the Agency avoided the Congressionally mandated scheme for addressing drugs not shown to be safe."

Some critics allege FDA footdragging amounts to deregulation by stealth. "We have to hold their feet to the fire," says Gail Hansen, senior officer for the Pew Campaign on Human Health and Industrial Farming in Washington, District of Columbia, and former state epidemiologist and state public health veterinarian for the Kansas Department of Health and Environment.

But FDA has gone considerably further than Canada in the area. Canadian efforts to contain antimicrobial resistance are stagnant (www.cmaj.ca/cgi /doi/10.1503/cmaj.109-3109), although experts say that the Public Health Agency of Canada's (PHAC) data warrant restrictions on off-label farm use of cephalosporins (www.cmaj.ca/cgi/doi /10.1503/cmaj.091009). FDA's ban on off-label use of cephalosporins was based in part on that data from the Canadian Integrated Program for Antimicrobial Surveillance. It is "one piece of a larger body of scientific data that supported our finding that extralabel uses of cephalosporin drugs in food-producing animals are likely contributing to cephalosporin-resistance in certain human pathogens," says William Flynn, deputy director for science policy at FDA's Center for Veterinary Medicine.
While some Canadian veterinary drug regulators are urging a crackdown (www.cmaj.ca/lookup/doi/10.1503/cmaj .109-4055) and an internal PHAC report concluded the government's oversight of antimicrobial resistance is deficient (www.cmaj.ca/lookup/doi/10.1503/cmaj .109-3921), many observers are convinced that the federal government is stalling.

In failing to act on data from Canadian government scientists, the federal government has created a situation in which the nation's regulatory regime is far laxer than in the US, says Jennifer Grant, a medical microbiologist at the Vancouver General Hospital and Health Services Centre, in Vancouver, BC. "We are not taking the opportunity to act on the evidence we are finding."

But Health Canada rejects that notion. The department has taken "a variety of measures to promote the judicious use of antimicrobial drugs in animals and to limit the development of antimicrobial resistance," spokeswoman Olivia Caron writes in an email. "These measures include the addition of warning statements specifying the conditions for antimicrobial use on the drug product labels. Health Canada is currently reassessing those antimicrobial drug products that make growth promotion claims." - Paul Christopher Webster, Toronto, Ont.

CMAJ 2012. DOI:10.1503/cmaj.109-4231 